\title{
A Framework for Product-Service Design for Manufacturing Firms
}

\author{
Thècle Alix and Bruno Vallespir \\ IMS, University of Bordeaux / CNRS, 351 Cours de la Libération, \\ 33405 Talence Cedex, France \\ \{thecle.alix, bruno.vallespir\}aims-bordeaux.fr
}

\begin{abstract}
Manufacturers propose services around the products they deliver to increase their competitiveness and reach objectives of profitability satisfying specific customer needs. Loyalty can be obtained under the condition that isolated offerings are replaced by integrated value adding solution composed of a product and of one or more product-service. The design of such solution requires to take account of four narrowly overlapping dimensions: the product, the product-service, the process and the organization. A challenge is to propose a model to support the firm core competence widening taking account of all the dimensions together, analyzing how they are interlinked and how they allow to design the coherent value adding solution. In this paper the two first stages of a methodology for new product-service development for manufacturing firms are presented that take account of firm's environment, core competence, processes as well as the benefits expected by service delivery and the service value.
\end{abstract}

Keywords: Product-service systems, service value, service engineering.

\section{Introduction}

Service activities have become since few years a current way to differentiate from competitors and make customers loyal. Manufacturers propose services around the main product they deliver and customer loyalty can be obtained under the condition that isolated offerings are replaced by integrated value adding solution composed of the product and associated product-service [1]. Consequently they must be thought and designed together before being sold as an integrated offer.

Even if currently the way of doing of industrialists is far from a co-design productservice system concept [2], a survey performed during the summer 2008 [3] has shown that most of the services proposed by big manufacturing companies are dedicated to the core product and that they are developed accordingly. For the most part, they are completely integrated in the product offer (for $75 \%$ of them) and performed by the manufacturing company (for 95\%). Underlying objective of profitability can be reached under the condition that firms manage all the changes that are necessary to deliver a service, as well as the transition allowing to reach the stable condition of product-service high value solution provider.

Changes to control can be split in: (i) Strategic changes due to the necessity to define common organization, management and control principles, (ii) Marketing 
changes as the analysis and understanding of the customers requirement to provide the good service (high value) is crucial, (iii) Commercial changes to determine the differentiation potential regarding competitors to valorize the offer and make it worth in the eyes of the customer, (iv) Economical changes as the product functionalities centric discourse had to be changed in an integrated value centric one to convince the customer and (v) Cultural modifications of firm employee's skills and focus that must be less technical and back office and more commercial and front office. The design and delivery of an integrated solution requires to take account of four narrowly overlapping dimensions related to: (i) the product (object that corresponds to the firm core competence, initial object of the selling), (ii) the product-service (service supplied in addition to the product and increasing its value for the customers), (iii) the processes (used to create the product and/or the product-service) and the organization (the context in which the process unfold is launched); while managing the value, risks and knowledge inherent to new development (Fig.1).

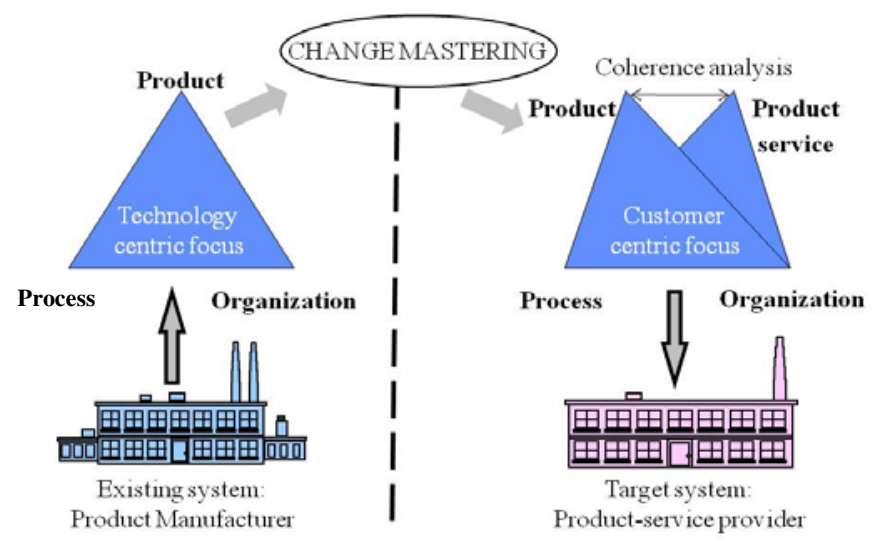

Fig. 1. From manufacturing business to product-service solution providers business.

Service research is wide and integrates different communities who have already responds to some problematic [4], [5], [6], [7] but as Wild et al. mentioned it "each discipline involved in service research appears to have their own dogma and mythology, and all too often end up with minimal interaction with relevant areas" [8]. A cross disciplinary approach could be useful to combine the points of views, analysis methodologies and tools to properly cover all the aspects of service delivery and to help characterize the stable condition abovementioned.

The challenge is then to propose a method to support firm core competence widening taking all the dimensions and changes into account, analyzing how they are linked and how they allow to design the coherent value adding solution using the most appropriate methodologies and tools whatever the discipline is concerned. To reach this objective, we propose to analyze new product-service development using a project management centric view as it encompasses the firm's environment, core competence, process, organization as well as benefits, risks and value. 


\section{Product-Service Design as a Project of New development}

Based on the previous hypothesis, we assume that the project of product-service development can be split as any project of product design in four main steps (Fig.2.):

- The first common step consists in a starting sequence and allows to analyze customer expectations and to explore the positioning of the firm. This is a sort of strategic analysis based among other things on the study of environmental factors and criteria allowing to determine the strengths, weaknesses, opportunities and threat of the new development and to choose between several different ones. This step is discussed in section 3 .

- The second step is a definition sequence that allows to precise the specifications of the product-service to deliver and its value for both the customer and the manufacturer. Based on a functional analysis and a value engineering approach, value results can be gathered in a matrix that can be used as a strategic tool to analyze the relevance of a product-service offer that integrates the costs of design and delivery as well as the mercantile strategy. This step is developed in section 4.

- The third step corresponds to the realization sequence whose objective is, in that particular case, to define the process from the design of the service to its delivery. The definition and modeling of the processes is out of the scope of this contribution.

- The fourth and final step is the closing sequence. It corresponds to the real service delivery to the customer and capitalization of project experience. This aspect is also out of the scope of this paper.

Support activities concerning delay, cost, risk, organization, communication and knowledge management specific to the project are mandatory to ensure the new development success. Main aspects of their concern are skimmed over in Fig.2.

\begin{tabular}{|c|c|c|c|c|c|}
\hline \multicolumn{6}{|c|}{ Project sequences } \\
\hline & & - Stating sequence & - Definition sequence - & Realization sequence & - Closing sequence $\longrightarrow$ \\
\hline 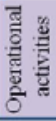 & & $\begin{array}{l}\text { Requirement analysis } \\
\text { Firm positioning }\end{array}$ & $\begin{array}{l}\text { Specification } \\
\text { of the service } \\
\text { Value analysis }\end{array}$ & $\begin{array}{l}\text { Definition of the } \\
\text { process from design } \\
\text { to delivery }\end{array}$ & $\begin{array}{c}\text { Service delivery } \\
\text { Project experience } \\
\text { capitalization }\end{array}$ \\
\hline \multirow{6}{*}{ 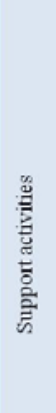 } & Delay & First planning - & Master Planning & Control Planning & Review Planning $\longrightarrow$ \\
\hline & Cost & - Resource evaluation & - Cost estimation & Expenses control & $\begin{array}{l}\text { Cost control } \\
\text { improvement }\end{array}$ \\
\hline & Risk & Risk analysis & Risk scenario & Hazard management & - $\begin{array}{c}\text { Risk control } \\
\text { improvement }\end{array}$ \\
\hline & Communication & $\begin{array}{l}\text { Informative } \\
\text { communication }\end{array}$ & $\begin{array}{l}\text { Definition of the } \\
\text { communication system }\end{array}$ & $\begin{array}{c}\text { Conflict } \\
\text { management }\end{array}$ & $\begin{array}{l}\text { Communication control } \\
\text { improvement }\end{array}$ \\
\hline & Knowledge & $\begin{array}{c}\text { Data } \\
\text { management }\end{array}$ & $\begin{array}{l}\text { Information } \\
\text { management }\end{array}$ & $\begin{array}{l}\text { Knowledge } \\
\text { management }\end{array}$ & $\begin{array}{l}\text { Knowledge control } \\
\text { improvement }\end{array}$ \\
\hline & Organization & $\begin{array}{l}\text { Project actor } \\
\text { identification }\end{array}$ & $\begin{array}{l}\text { Project } \\
\text { structuring }\end{array}$ & Project control & $\begin{array}{c}\text { Organization } \\
\text { improvement }\end{array}$ \\
\hline
\end{tabular}

Fig. 2. Sequences and activities of a project of new product-service development 
This project must also come within the scope of the firm and be coherent with the core product development, existing process and organization. This implies that all the data related to these 3 items have to be compiled with data coming from the operational and support activities as sort of control.

\section{Starting Sequence}

As outlined in section 2, the starting sequence proceeds to a strategic analysis that consists in a diagnosis and strategic segmentation [9]. The diagnosis can be performed using the SWOT matrix.

\subsection{The SWOT Matrix to Diagnose and Position the Firm}

The SWOT analysis (Strengths, Weaknesses, Opportunities and Threats analysis) is a tool for auditing an organization and its environment. It can help managers to determine if their objective -in term of new development for example- is attainable or not by the identification of internal and external key factors useful to achieve them. The SWOT analysis gathers key pieces of information in two main categories:

- Internal factors cover strengths and weaknesses internal to the organization that are helpful or harmful to achieve the objective. Usually, they include the 4P's of mix marketing (Product, Price, Place, Promotion); as well as personnel, finance, manufacturing capabilities, etc. The customer's requirements in term of service associated to the product are taken into account by the way of the mix marketing study that will reveal the components of the value for the customers. Note that in that case the first $\mathrm{P}$ stands for product-service.

- External factors concern opportunities and threats that are helpful or harmful external conditions to achieve the objective. They include macroeconomic matters, technological change, legislation, and socio-cultural changes, as well as changes in the marketplace or competitive position.

All these factors gathered in a matrix permit to define the risks and benefits of a new product development strategy. If the objective is attainable, the SWOTs can be used as inputs to the creative generation of possible further strategies.

\subsection{List of Internal Factors: Strengths and Weaknesses}

The identification of strengths and weaknesses can be done regarding inside the firm and analyzing its culture and main economic functions in term of organization, product and process and their interrelations. Then, taking account of the changes mentioned in section 1, internal factors may stem from:

- Firm culture and organization: enterprise identity, brand image, organisation structure mode; industry specialization; project experience, membership, sales office;

- Marketing and commercial ins and outs aspects: market share, Product-service / Price / Place / Promotion coherence; 
- Human resources ins and outs: skills; motivation, involvement, project team, project manager, top management commitment, contact personnel training, contact personnel quality, sales team;

- Financial ins and outs: results, benefits, possibilities of investment and investors;

- Technical ins and out as a product-service can be material or not and/or technologically complex in particular if it uses TIC. Then factors coming from design (technological innovation potential, R\&D opportunities) and production (Capacity/load ratio; Delay; Partners relationship; Resource competencies, stock level Production, service definition, process definition identified procedures) are relevant to analyze product-service development.

The Justification of Each Factor and Sub Factor Is Given in [14]

\subsection{List of External Factors: Opportunities and Threats}

External factors stem from the study of the micro-, macro- and meso-environment of the firm. The Macro-environment picture can be obtained by the way of a PEST analysis (Political (and legal), Economic, Social, Technological). The PEST factors can be used to assess the market for a business or organisational unit strategic plan [10]. The micro-environment can be studied by analysing the firm' strength and weakness regarding the five strengths of its sector of activity: the relationship with its customers, with its suppliers, the competitor's pressure, the threat of new competitors and the substitute products [11]. The Meso-environment focuses on person that could influence the economical relations in a market. The list of external factors and sub factors of interest is detailed in [10].

\subsection{Definite List of Factors}

The factors abovementioned can be gathered by aggregation and according to their relevance in the following set: Project team, Manufacturing resources, Technological potentiality, Operations/ process, Partners relationship, Brand image, Cost base, Cash flow, Sales team, Distribution, Political environment, Economic outlook, Cultural changes, Technical context, Customers position, Suppliers position, Competitors position, Substitute, Product to integrate [14].

Note that we do not mention if an internal factor is a strength or a weakness as there is a continuum between both; id. for the threats and opportunities. The project team leader will first have to determine the consequences of a factor: whether it is a benefit (strength or opportunity) or a risk (weakness or threat). Subsequently, the relevance of each internal factor as well as the probability of occurring of each external factor will be defined. Finally the impact of each factor on the organisation could be discussed and results plotted in a chart (see (c) Copyright MarketWare International 2001-2004). A visual representation of the risks and benefits of a new product-service development could be obtained and compared to other ones. The position of the firm will result from the comparison that takes parameters relative to the product, organisation and processes into account by the way of the factors. 


\section{Definition Sequence}

The definition sequence consists, once the development direction is chosen, in defining the solution that will be profitable for both new manufacturer and customers; to determine its position in the portfolio of the firm and its legitimacy to be proposed and enhance firm competitiveness and profitability.

This second stage rests on the use of the value analysis methodology and compares the value of the offer for the manufacturer taking account of its expected benefits and the value of the same offer for the customers defined by the way of expected quality criteria. All these developments are based on the assumption that the value can be defined by the ratio between the performance of some functions and their cost [12].

Currently two functions are defined: (i) "basic function" which correspond to anything that makes the product work or sell and (ii) "secondary functions" or "supporting functions" that describe the manner in which the basic function(s) are implemented.

\subsection{Product-Service Value Analysis: From the Manufacturer Point of View}

We assume that the functions which participate to the definition of the value for the provider focus on the expected benefits of a product-service proposal. Based on [13] and a literature review in the management area, benefits usually mentioned concern: (i) the construction of a customer loyalty by the building of dependency relationships between a consumer and a provider that can lead toward profitability, (ii) the search for differentiation that allows retaining and attracting consumers, (iii) the increase and stabilizing of firms' turnover due to the possibility to generate regular income and to have cash flow disposal, (iv) the corporate image reinforcement linked to technological advanced, product quality... (v) the occupation of an existing or new market to participate to market share division, (vi) the possibility to create alliance with service providers and to share risks, (vii) the possibility to increase the quickness of a design or production process using product-service based on information and communication technologies, (viii) the possibility to shorten sales delay or negotiation phase using financial services and (ix) the search for a product-service system that is designed to have a lower environmental impact than traditional business models [14].

Each benefit can be defined as expected performances that stem from a strategy and have priorities one to the other. Quantifiable criteria can be associated to each one whose level also stem from the strategy. The level really measured, that reflect the performance of the function, compared to the global cost of the service allows to determine the value of the service for the firm.

Costs to take into account can be divided in direct and indirect costs. Regarding product-service characteristics, several costs can be addressed that depends (i) on its degree of tangibility, (ii) on the degree of interaction that is necessary between the firm contact personnel and the customer to deliver it and, (iii) on the degree of standardization of the product-service delivery process. They can encompass component costs, cost of labor, and overheads.

The description of the functions from the manufacturer point of view and the consciousness of the product-service costs allow to build a value analysis matrix [14]. 


\subsection{Product-Service Value Analysis: From the Customer Point of View}

According to [15], customers challenge the overall value of an offer to its complete cost. The overall value refers to the different advantages obtained, supported by the firm brand image. Advantages may gather both benefits expected on technical functionalities and subjective criteria as lots of studies have shown that customers are waiting for something from the exchange with the firm. [16] has proposed a list of criteria and dimensions allowing to evaluate the quality of a standard service These criteria can be associated to implicit functions whose fulfillment can lead to customer loyalty and value increase.

Then, the list of functions of a product-service expected by customers consists in: (i) the product-service raison d'être: help choosing, acquiring or using the main product [1], (ii) secondary functions linked to its interactions with the contact personnel, users and means necessary to realize it, the partners, environmental and legislative constraints and the realization constraints as mentioned previously and, (iii) the implicit functions coming from quality criteria discharged from the functions that refers to the delivery process: to obtain a tangible service.

The value determined by the firm from the customer point of view will be determined by putting in opposite the previous list of function and the distribution of the above mentioned costs via another value analysis matrix.

\subsection{Synthesis}

Using aggregation operator, it is possible to deduce the whole value of the productservice proposed by a manufacturing firm. This one can have two positions: high or low and can be analyzed regarding two dimensions: the customer dimension and the firm dimension Fig.3.

\begin{tabular}{|c|c|l|l|}
\cline { 3 - 4 } \multicolumn{1}{|c|}{} & \multicolumn{1}{|c|}{ High } & \multicolumn{1}{c|}{ Low } \\
\cline { 3 - 4 } $\begin{array}{c}\text { Customer } \\
\text { value }\end{array}$ & High & $\begin{array}{l}\text { The product service is profitable } \\
\text { for the firm and satisfies } \\
\text { customers. It might accompany } \\
\text { the product }\end{array}$ & $\begin{array}{l}\text { To make the customer loyal, firm may } \\
\text { propose the service but found solution to } \\
\text { increase its value by decreasing its price } \\
\text { if it is worth in the eye of the consumer } \\
\text { or adding others services located in the } \\
\text { high/high value. }\end{array}$ \\
\cline { 2 - 3 } & Low & $\begin{array}{l}\text { This position is synonymous of } \\
\text { customer loyalty if the customer } \\
\text { participates or if the cost of the } \\
\text { offer is not too important. } \\
\text { Otherwise, he won't be interested } \\
\text { by this list of sales point. }\end{array}$ & $\begin{array}{l}\text { The abandon of the product-service or } \\
\text { not will depend on the cash that is } \\
\text { necessary to provide it or on the } \\
\text { delivering difficulties }\end{array}$ \\
\hline
\end{tabular}

Fig. 3. Value matrix

The value analysis of each product-service coherent with the firm position from the two points of view will provide a synthetic view of the equilibrium of the global offer. To ensure firm global profitability, the portfolio of product-services has to be shared out between all categories (High/low). 


\section{Conclusion}

We have proposed in this contribution the two first steps of a methodology in four steps to support manufacturing firm core competence widening by the furniture of product-service taking account of the changes that are necessary to become a "service" as well as the product, the organization and its process. The first step developed here provides keys to choose an orientation for product-service new development. The second step allows to analyze the relevance of a product-service offering based on its value analysis. Further works include the definition of tools to help characterize the two last steps as well as a refinement of the two first one.

\section{References}

1. Furer, O.: Le rôle stratégique des services autour des produits. In: Revue Française de Gestion, mars-avril-mai, pp. 98-108 (1997)

2. Baines, T.S., et al.: State-of-the-art in product-service systems. In: Proceedings of the Institution of Mechanical Engineers. Part B. Journal of engineering manufacture, vol. 221(10), pp. 1543-1552. Mechanical Engineering Publications, London (2007)

3. Alix, T., Touzy, W., Vallespir, B.: Product-service value analysis: two complementary points of view. In: Proc of the 13th IFAC Symposium on Information Control Problems in Manufacturing (2009)

4. Berry, L.L.: Relationship marketing of services - growing interest, emerging perspectives. Journal of the Academy of Marketing Science 23(4), 236-245 (1995)

5. Fisk, R.P., Grove, S.J., John, J.: Services Marketing Self-Portraits: Introspections, Reflections, and Glimpses from the Experts. American Marketing Association, Chicago (2000)

6. Lovelock, C., Wirtz, J., Lapert, D.: Marketing des services. Pearson Education, London (2004)

7. Zeithaml, V.A., Berry, L.L., Parasuraman, A.: The behavioral consequences of service quality. Journal of Marketing 60, 31-46 (1996)

8. Wild, P.J., Clarkson, P.J., Mc Farlane, D.C.: A framework for Cross Disciplinary Efforts in Services Research. In: Proc of CIRP IPS2 Conference, pp. 145-152. Cranfield Univeristy Press, United Kingdom (2009)

9. Alix, T., Vallespir, B.: New product development: material versus immaterial. In: Proc of Extended Product and Process Analysis aNd Design EXPPAND workshop (2009)

10. Armstrong, M.: A handbook of Human Resource Management Practice, 10th edn. Kogan Page, London (2006)

11. Porter, M.E.: The Competitive Advantage: Creating and Sustaining Superior Performance. Free Press, N.Y (1985)

12. Goyhenetche, M.: Le marketing de la valeur, Créer de la valeur pour le client. INSEP (1999)

13. Baglin, G., Malleret, V.: Le developpement d'offres de services dans les PMI. Cahier de recherché du groupe HEC (2005)

14. Alix, T., Ducq, Y., Vallespir, B.: Product-service value analysis: two complementary points of view. In: Proc of CIRP IPS2 Conference, pp. 157-164. Cranfield Univeristy Press, United Kingdom (2009)

15. Hermel, L., Louyat, G.: La qualité de service. AFNOR, France (2005)

16. Zeithmal, A., Parasuraman, A., Berry, L.: Delivering quality service. The free Press, New York (1991) 